\title{
Assessment of liver marker enzymes and its association with type 2 diabetes mellitus in Northwest Ethiopia
}

\author{
Tewodros Shibabaw¹, Gashaw Dessie ${ }^{1}$, Meseret Derbew Molla', Muluken Fekadie Zerihun \\ and Birhanu Ayelign ${ }^{2 *}$
}

\begin{abstract}
Objective: This study aimed to assess the level of aspartate aminotransaminase (AST), alanine aminotransaminase (ALT) and gamma-glutamyltransferase (GGT), and their association with type 2 diabetes mellitus in Northwest Ethiopia.

Results: Using a cross-sectional study, blood samples were collected from 192 Type 2 diabetes mellitus (T2DM) participants and 192 healthy age and sex-matched volunteers. The study was carried out from May to August 2017. The serum concentration of aspartate aminotransaminase, alanine aminotransaminase, and gamma-glutamyltransferase were measured using A25 Bio-system fully automatic chemistry analyzer and using the manufacturer's kit of the machine. Liver function test results of T2DM participant were significantly higher than those of the control group, serum ALT (46.06 $\pm 22.38 \mathrm{IU} / \mathrm{L}$ ) and serum AST (42.94 $\pm 19.08 \mathrm{IU} / \mathrm{L}), \mathrm{P}<0.001$, while the level of GGT in both study groups was not significantly associated $(P=0.065)$. In conclusion, the evaluation of liver marker enzymes showed a significant association with Type 2 diabetes participants compared with the controls.
\end{abstract}

Keywords: Gamma-glutamyltransferase, Aspartate aminotransaminase, Alanine aminotransaminase

\section{Introduction}

Diabetes mellitus is a heterogeneous group of disorders characterized by persistent hyperglycemia with carbohydrate, lipid, and protein metabolism resulting from defects in insulin secretion and/or insulin action [1,2]. Type 2 diabetes is caused by impaired $\beta$-cells function and capacity to secrete sufficient insulin, coupled with a decline in target tissue sensitivity to insulin (insulin resistance) [3,4]. Globally, type 2 diabetes is one of the most common non-communicable diseases, which is increasing at an alarming rate and affecting a significant number of people. It is rapidly rising as a global health care problem and threatening to reach endemic levels by

\footnotetext{
*Correspondence: birhanuayelign42@gmail.com

2 Department of Immunology and Molecular Biology, School of Biomedical and Laboratory Science, College of Medicine and Health Sciences, University of Gondar, Gondar, Ethiopia

Full list of author information is available at the end of the article
}

2030 , especially in low and middle income countries $[1$, $5,6]$.

This metabolic disorder (diabetes) affects many organs, including the liver, which plays a key role in the regulation of carbohydrate, lipid, and protein metabolism [7]. Elevated serum aminotransferases level; Aspartate aminotransferase (AST), alanine aminotransferase (ALT) and $\gamma$-glutamyltransferase (GGT) were commonly observed in diabetes $[8,9]$. Alanine aminotransferase and aspartate aminotransferase are the most specific marker of hepatic injury, which is located in the hepatocellular cytosol and mitochondria, respectively $[10,11]$. A recent report shows a significant association of increased ALT and AST with insulin resistance, T2DM, and metabolic syndrome $[9,12]$. Gamma-glutamyltransferase (GGT) is located on the external surface of most cells and mediates the uptake of glutathione, an important component of intracellular antioxidant defenses [13-15]. An increase in GGT concentration has been regarded as a marker of alcohol-associated liver disease than diabetes associated 
hepatic injury [14]. Even though, diabetes is one of the major public health problems in Ethiopia, there is are highly limited documented and updated articles on the association of diabetes with hepatic injury/dysfunction. Since there is no adequate studies conducted have been to the best of our knowledge, the current study we hope will fill the existing gap in the association of the liver marker enzymes with T2DM. Therefore, we aimed to assess liver enzyme tests, such as ALT, AST and GGT and their association with Type 2 diabetes as compared with non-diabetes control groups in north west Ethiopia.

\section{Main text}

\section{Materials and methods}

\section{Study design, sampling technique, and sample size} determination

A cross-sectional study was conducted at north west Ethiopia from May to August 2017. A single population proportion formula was used to calculate the sample size, $\mathrm{n}=\mathrm{Z}^{2} \mathrm{p}(1-\mathrm{p}) / \mathrm{d}^{2}$, where: $\mathrm{Z}=\mathrm{Z}$ score at $95 \%$ confidence interval $=1.96$ with power $=0.80, p=$ prevalence $=50 \%$, $\mathrm{d}=$ mariginal error $=5 \%(0.05) . \mathrm{N}=(1.96)^{2} 0.5(1-0.5) /$ $(0.05)^{2}=384$, Finally, a total of 384 study participants were selected by using the simple random sampling technique. We nominated an equal number of cases (diabetes) and control (apparently healthy) study participants, 192 for each group.

\section{Inclusion and exclusion criteria}

Participants with confirmed diabetes mellitus or newly diagnosed diabetes using WHO guidelines [16], fasting plasma venous glucose of $\geq 7 \mathrm{mmol} / \mathrm{L}(126 \mathrm{mg} / \mathrm{dL})$ or random plasma venous glucose of $\geq 11.1 \mathrm{mmol} / \mathrm{L}$ $(200 \mathrm{mg} / \mathrm{dL})$ were included, while exclude the diabetes participants with history of liver disease, alcohol intake, hepatotoxic drugs, clinical evidence for acute hepatitis, participants with hepatitis $B$ and $C$ virus infection, and participants with clinical and subclinical hypothyroidism was excluded.

\section{Blood sample collection, analysis and quality assurance}

The interviewer was particularly planned to obtain information, which helps to screen participants on the eligibility criteria. Five milliliters $(5 \mathrm{~mL})$ of venous blood was drawn from each volunteer participant using disposable plastic syringes. The blood was poured into a plane containers and centrifuged after clotting. Serum was kept at $-20{ }^{\circ} \mathrm{C}$ in sterile circumstance at the University of Gondar compressive specialized hospital laboratory until the analysis was done. SGOT, SGPT, and GGT were determined by means of enzymatic tests using the A25 Bio-system human (German). The normal value of each test was based on the reference of enzymatic test of A25
Bio-system human (German) kit. Data quality management/control Training was provided for data collectors and supervisors about the purpose of the study, data collection process, laboratory analysis, and ethical issues. The sample was received, accessioned and processed according to the standard operational procedure. Strict supervision and monitoring were also performed during the data collection period by supervisors and investigators. The standard operational procedure was addressed in the pre-analytic, analytic and post-analytic stages of laboratory services which constituted and impacted the overall quality of the laboratory analysis. Data was also cleaned up and cross checked to control irregularities.

\section{Statistical analysis}

Data were double entered and cleaned using Epi Data 3.1 (Jens M. Lauritsen \& Michael Bruus) and transferred to SPSS version 20 (IBM, New York, and U.S) and presented as mean \pm SD values. Statistical analysis was done by using an independent $t$ test to find out the difference between the two unpaired groups. P 0.05 was considered statistically significant.

\section{Result}

A total of 384 participants (192 confirmed T2DM and 192 controls) were enrolled in this study. The mean ages of the T2DM and controls participants were $55.76 \pm 10$. 11 and $50.93 \pm 5.41$, respectively. Men constituted 121 (63\%) of T2DM participants and $116(60.4 \%)$ of the controls. Sixty-nine $(35.9 \%)$ of the diabetes case and $54(28.1 \%)$ of controls completed secondary school; 92 (47.9\%) of the case and 67 (34.9\%) of the controls were merchants and civil servants, respectively (Table 1).

In this study, 93 (48.4\%) of diabetes participant and 8 (4.2\%) of control had elevated serum AST levels. Of all the diabetes case, 77 (40.1\%) had elevated serum ALT, and $192(100 \%)$ of control group had normal values of ALT. In addition, $3(1.6 \%)$ of diabetes case and $1(0.5 \%)$ of the controls had elevated serum GGT levels (Fig. 1).

The mean values of ALT and AST were significantly higher in type 2 diabetes participants than the control group $(\mathrm{P}<0.001)$ as shown in Table 2 . The GGT level of the control group and that of the diabetes participants was not associated significantly $(P=0.065)$. The mean value of fasting blood glucose of in T2DM was significantly higher than that of control group $(\mathrm{P} \leq 0.001)$ as illustrated in Table 2.

\section{Discussion}

In the present study, the mean age of the diabetes and the control group were 56 and 52 years, respectively. Acute and subclinical hepatocellular disturbance might influence plasma glucose homeostasis. Due to the fact that, 
Table 1 Socio-demographic characteristics of study participants $(\mathrm{N}=384)$, North West Ethiopia, 2017

\begin{tabular}{|c|c|c|}
\hline Characteristics & Patient $(n=192) N(\%)$ & Control $(n=192) N(\%)$ \\
\hline \multicolumn{3}{|l|}{ Sex } \\
\hline M & $121(63 \%)$ & $116(60.4 \%)$ \\
\hline $\mathrm{F}$ & $71(37 \%)$ & $76(39.6 \%)$ \\
\hline Age (Mean $\pm S D)$ & $55.76 \pm 10.11$ & $50.93 \pm 5.41$ \\
\hline \multicolumn{3}{|l|}{ Religious } \\
\hline Orthodox & $131(68.2)$ & $148(77.1)$ \\
\hline Muslim & $35(18.2)$ & $34(17.7)$ \\
\hline Protestant & $14(7.3)$ & $7(3.6)$ \\
\hline Catholic & $12(6.3)$ & $3(1.6)$ \\
\hline \multicolumn{3}{|l|}{ Education } \\
\hline Illiterate & $40(20.8)$ & $39(20.3)$ \\
\hline Primary school & $69(35.9)$ & $77(40.1)$ \\
\hline Secondary school and college & $69(35.9)$ & $54(28.1)$ \\
\hline Degree and above & $14(7.3)$ & $22(11.5)$ \\
\hline \multicolumn{3}{|l|}{ Occupation } \\
\hline Farmer & $17(8.9)$ & $17(8.9)$ \\
\hline Merchant & $92(47.9)$ & 79(41.1) \\
\hline Civil servant & $72(37.5)$ & 64(33.3) \\
\hline Student & $6(3.1)$ & $12(6.3)$ \\
\hline Other & $5(2.6)$ & $20(10.4)$ \\
\hline
\end{tabular}

F Female, IU/L International units per liter, $M$ male, $\mathrm{mg} / \mathrm{dl}$ milligrams per deciliter, $N$ number, $n$ number, $S D$ standard deviation

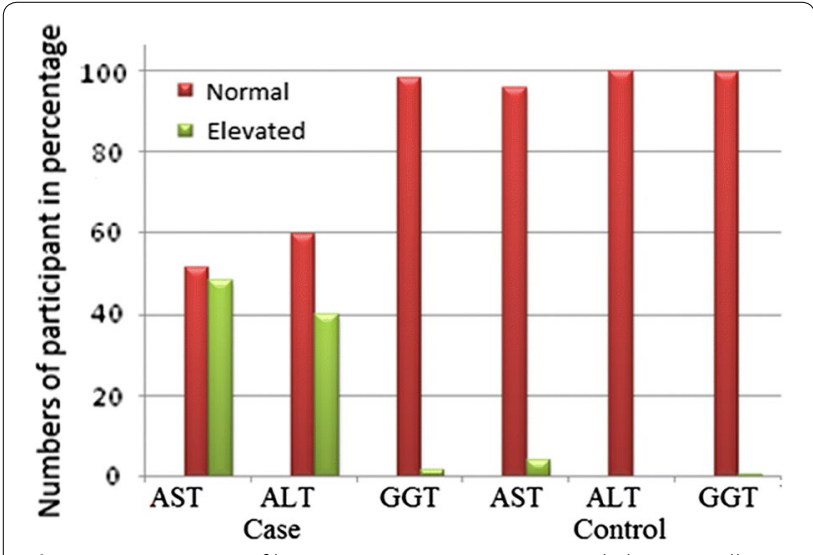

Fig. 1 Comparison of liver enzymes among type 2 diabetes mellitus participant and control groups. AST Aspartate aminotransaminase, ALT alanine aminotransaminase, GGT gamma glutamyltransferase

we can understand that liver enzymes are not the only markers of liver dysfunction, which also have a predictive value to assess the severity of diabetes. Insulin resistance is a typical feature of T2DM, which shows that abnormality in glucose homeostasis by the liver [17]. Glycation is the most common complication of T2DM that results oxidative stress in tissue [18]. This oxidative stress and cytokine production in the liver cause alterations of liver enzymes due to the hepatocellular damage $[19,20]$. Thus,
Table 2 Biochemical parameters among diabetes and control participant (as mean \pm SD) $(N=384)$, Northwest, Ethiopia, 2017

\begin{tabular}{lllll}
\hline Parameters & $\begin{array}{l}\text { DM } \\
\text { participants } \\
\text { (mean } \pm \text { SD) }\end{array}$ & $\begin{array}{l}\text { Control } \\
\text { group } \\
\text { (mean } \pm \text { SD) }\end{array}$ & $\begin{array}{l}\boldsymbol{P} \text { value } \\
\text { FBS(mg/dl) }\end{array}$ & $\begin{array}{l}\text { Laboratory } \\
\text { reference } \\
\text { range }\end{array}$ \\
AST(IU/L) & $42.94 \pm 19.08$ & $20.34 \pm 9.90$ & $<0.001$ & $0-37 \mathrm{U} / \mathrm{L}$ \\
ALT(IU/L) & $46.06 \pm 22.38$ & $22.66 \pm 9.45$ & $<0.001$ & $0-42 \mathrm{U} / \mathrm{L}$ \\
GGT & $21.98 \pm 8.36$ & $20.28 \pm 9.63$ & 0.065 & $0-48 \mathrm{U} / \mathrm{L}$
\end{tabular}

DM Diabetes Mellitus, International Units per Liter, $\mathrm{mg} / \mathrm{dL}$ milligrams per deciliter, SD standard deviation

further results dysregulation of blood glucose maintenance, since it plays a key role in such maintenance [21]. This condition results in the abnormal introduction of liver enzymes into the circulation and become elevated. In the present study, we have assessed the level of liver enzymes, including ALT, AST, and GGT among age-sex matched T2DM participants and an apparently healthy control groups.

In this study, 93 (48.4\%) of the diabetes case and 8 (4.2\%) of the control group had elevated serum AST levels. Among the case groups, 77 (40.1\%) of them had elevated serum ALT whereas 192 (100\%) of the control group had normal values. The result showed that the 
mean values of AST and ALT significantly increased in T2DM participants compared with the controls group. Our findings were in line with a study conducted in Iraq and India in which the elevation of AST and ALT were statistically associated with T2DM [20, 22]. Likewise, a recent study in Myanmar and Singapore demonstrated that the mean values of ALT and AST were within the reference range among the diabetes participants [23]. In contrast to our finding, the level of GGT was statistically significant with T2DM in the two studys above stated [20]. Elevated ALT and AST value were observed in $18.5 \%$ and 14.8 in the T2DM participants, respectively [24]. A similar finding was reported in India, which investigated 90 T2DM for liver enzyme, ALT and 90 healthy subjects as control group [20].

Serum ALT $(71.65 \pm 23.3)$ levels were elevated significantly among $36(40 \%)$ of the T2DM participants [10, 24]. Similarly, our result were in agreement with a study conducted on Sudanese diabetes participants and 50 apparently healthy control subjects. The result of this study showed that the mean values of ALT and AST were significantly higher in T2DM than the control group $[9,12]$. Even if the mean values were within the normal range, 11 T2DM participants (22\%) had at least one or more abnormal liver enzymes [12, 25]. On the other hand, in this study, GGT was not significantly associated with the risk for diabetes. In contrast to this, another study indicated that GGT was significantly associated with the risk among diabetes participants compared to controls [13]. This study suggested that an increase in GGT concentration was a perceptive and an early biomarker of the development of diabetes.

Our study evaluated the presence of elevated levels of liver marker enzymes among T2DM participants. This may be due to increases in glycogen/insulin effect on liver cells. The increase of glycogenolysis (breakdown of stored glycogen) and gluconeogenesis (glucose production from non-carbohydrate precursors) becomes the primary metabolic pathway [26]. Thus, increases in substrate delivery (e.g. alanine) and in the conversion of alanine to glucose might be regulated as a compensatory mechanism for impaired hepatic insulin communication transduction, which allows the enzyme to leak out of hepatocytes, mainly due to the infiltration of fat accumulation as well as hepatic cell injury [23]. An abnormal accumulation of fat and its mobilization in hormone-sensitive tissues (liver) and hepatocytes demonstrate a metabolic switch through insulin resistance identified earlier than the fasting elevation of blood sugar. The overloaded release of free fatty acids due to insulin resistance induces fat mobilization and results in the toxicity of hepatocytes [20]. The elevation of the transaminase enzymes is directly linked to liver cell damages. The rupture of a plasma membrane at high concentrations of the metabolites, loss of mitochondrial activities and the inactivation of the regulatory metabolic enzymes results in hepatic cell injury [27]. In conclusion, the result of this study showed that the elevation of the liver enzyme test (ALT and AST) was significantly associated with type 2 diabetes mellitus compared with the control group. Therefore, liver enzyme tests might have a positive role in the management of diabetes.

\section{Limitations of the study}

The use of limited number of biochemical parameters and the absence of invasive liver biopsy procedures to assess liver histopathological changes is one of the limitation of our work. Further clarification is necessary for large sample studies to exactly illustrate a comprehensive conclusion of liver function tests in a person with T2DM.

\section{Abbreviations \\ WHO: Health Organization; AST: aspartate aminotransaminase; ALT: alanine aminotransaminase; T2DM: type 2 diabetes mellitus; BMI: body mass index; GGT: gamma glutamyltransferase.}

\section{Acknowledgements}

We are profoundly grateful thank you to the University of Gondar, the study participants and people that assisted this project.

\section{Authors' contributions}

Conception of the research idea, study design: TS and BA; Data collection, part of laboratory work: BA, GD. Data analysis and reviewed the manuscript: TS, BA, MF, GD and MD. All authors read and approved the final manuscript.

\section{Funding}

For this research paper, we didn't receive any grant from any funding agency.

\section{Availability of data and materials}

Relevant data used could be made available with in this manuscript.

\section{Ethics approval and consent to participate}

The study was reviewed and approved by the University of Gondar ethical committee (O/N/P/RCS/05/360/). Each study participant was informed about the objective of the study that contributes necessary information for policymakers and other concerned bodies. Informed written consent was obtained from study subjects before we asked them to give a sample. Participants were informed that they have the full right to continue or withdraw from the study at any time and all the information and results of the study subject would be kept confidentially.

\section{Consent for publication}

Not applicable.

\section{Competing interests}

The author(s) declare(s) that there is no conflict of interest regarding the publication of this paper.

\section{Author details}

${ }^{1}$ Department of Biochemistry, School of Medicine, College of Medicine and Health Sciences, University of Gondar, Gondar, Ethiopia. ${ }^{2}$ Department of Immunology and Molecular Biology, School of Biomedical and Laboratory Science, College of Medicine and Health Sciences, University of Gondar, Gondar, Ethiopia. 
Received: 30 September 2019 Accepted: 16 October 2019

Published online: 29 October 2019

\section{References}

1. Whiting DR, Guariguata L, Weil C, Shaw J. IDF diabetes atlas: global estimates of the prevalence of diabetes for 2011 and 2030. Diabetes Res Clin Pract. 2011:94(3):311-21.

2. Chen L, Magliano DJ, Zimmet PZ. The worldwide epidemiology of type 2 diabetes mellitus - present and future perspectives. Nat Rev Endocrinol. 2012;8(4):228

3. Control CfD, Prevention. Prevalence of overweight and obesity among adults with diagnosed diabetes-United States, 1988-1994 and 1999-2002. MMWR Morb Mortal Wkly Rep. 2004;53(45):1066.

4. Bluestone JA, Herold K, Eisenbarth G. Genetics, pathogenesis and clinical interventions in type 1 diabetes. Nature. 2010;464(7293):1293.

5. Haslam D, James W. Obesity Lancet 2005; 366: 1197-209. CrossRef, PubMed, Web of Science ${ }^{\circledR}$ Times Cited.782.

6. Zheng Y, Ley SH, Hu FB. Global aetiology and epidemiology of type 2 diabetes mellitus and its complications. Nat Rev Endocrinol. 2018;14(2):88.

7. Levinthal GN, Tavill AS. Liver disease and diabetes mellitus. Clin Diabetes. 1999;17(2):73-93.

8. Everhart EA. Diabetes in America: National Institutes of Health, National Institute of Diabetes and Digestive; 1995

9. Sheng X, Che H, Ji Q, Yang F, Lv J, Wang Y, et al. The relationship between liver enzymes and insulin resistance in type 2 diabetes patients with nonalcoholic fatty liver disease. Horm Metab Res. 2018;50(05):397-402.

10. Music M, Dervisevic A, Pepic E, Lepara O, Fajkic A, Ascic-Buturovic B, et al. Metabolic syndrome and serum liver enzymes level at patients with type 2 diabetes mellitus. Med Arch. 2015;69(4):251.

11. Vernon G, Baranova A, Younossi Z. Systematic review: the epidemiology and natural history of non-alcoholic fatty liver disease and non-alcoholic steatohepatitis in adults. Aliment Pharmacol Ther. 2011;34(3):274-85.

12. Idris AS, Mekky KFH, Abdalla BEE, Ali KA. Liver function tests in type 2 Sudanese diabetic patients. Int J Nutr Metab. 2011;3(2):17-21.

13. Lee D-H, Ha M-H, Kim J-H, Christiani D, Gross M, Steffes M, et al. Gammaglutamyltransferase and diabetes_-a 4 year follow-up study. Diabetologia. 2003;46(3):359-64.

14. Meisinger $C$, Löwel H, Heier M, Schneider A, Thorand B, Group KS. Serum $\gamma$-glutamyltransferase and risk of type 2 diabetes mellitus in men and women from the general population. J Intern Med. 2005;258(6):527-35.
15. Mansour A, Mohajeri-Tehrani MR, Samadi M, Gerami H, Qorbani M, Bellissimo N, et al. Risk factors for non-alcoholic fatty liver disease-associated hepatic fibrosis in type 2 diabetes patients. Acta Diabetol. 2019. https:// doi.org/10.1007/s00592-019-01374-x.

16. Organization WH. Definition and diagnosis of diabetes mellitus and intermediate hyperglycaemia: report of a WHO/IDF consultation. 2006.

17. Govindarajan G, Gill H, Rovetto M, Sowers JR. What is insulin resistance? Metab Syndr Manage. 2006;30:30-4.

18. Bigagli E, Lodovici M. Circulating oxidative stress biomarkers in clinical studies on type 2 diabetes and its complications. Oxid Med Cell Longev. 2019. https://doi.org/10.1155/2019/5953685.

19. Mathur S, Mehta DK, Kapoor S, Yadav S. Liver function in type-2 diabetes mellitus patients. Int J Sci Stud. 2016;3(10):43-7.

20. Sunitha S, Gandham R, Wilma DS, Rao S. Evaluation of significance of liver enzymes as screening tests for the early detection of clinically asymptomatic non alcoholic fatty liver disease in type 2 diabetes mellitus patients. Int J Biomed Adv Res. 2015;6(12):860-3.

21. Prabhudeva N, Pasha G, Mounika K. Hepatic dysfunction in diabetes mellitus: biochemical and ultrasonological study. J Acad Ind Res. 2014:3:164-7.

22. Judi L, Toukan A, Khader Y, Ajlouni K, Khatib MA. Prevalence of elevated hepatic transaminases among Jordanian patients with type 2 diabetes mellitus. Ann Saudi Med. 2010;30(1):25.

23. Wang Y-L, Koh W-P, Yuan J-M, Pan A. Association between liver enzymes and incident type 2 diabetes in Singapore Chinese men and women. BMJ Open Diabetes Res Care. 2016;4(1):e000296.

24. $\mathrm{Ni} \mathrm{H}$, Soe HHK, Htet A. Determinants of abnormal liver function tests in diabetes patients in Myanmar. Int J Diabetes Res. 2012;1 (3):36-41.

25. Atiba AS, Oparinde DP, Babatunde OA, Niran-Atiba T, Jimoh AK, Adepeju A. Liver enzymes and lipid profile among type 2 diabetic patients in Osogbo, Nigeria. Greener J Med Sci. 2013;3(5):174-8.

26. Balaji AS, Suhas BJ, Ashok MA, Mangesh T. Serum alanine transaminases and lipid profile in type 2 diabetes mellitus Indian patients. J Res Diabetes. 2013. https://doi.org/10.5171/2013.613176.

27. Harris EH. Elevated liver function tests in type 2 diabetes. Clin Diab. 2005:23(3):115-9.

\section{Publisher's Note}

Springer Nature remains neutral with regard to jurisdictional claims in published maps and institutional affiliations.
Ready to submit your research? Choose BMC and benefit from:

- fast, convenient online submission

- thorough peer review by experienced researchers in your field

- rapid publication on acceptance

- support for research data, including large and complex data types

- gold Open Access which fosters wider collaboration and increased citations

- maximum visibility for your research: over $100 \mathrm{M}$ website views per year

At BMC, research is always in progress.

Learn more biomedcentral.com/submissions 